\title{
Construction of toll station building on the highway
}

\author{
Matej Lozančić, M.Eng.C.E. \\ Vlaho Akmadžić \\ University of Mostar, Faculty of Civil Engineering, Ph.D C.E. \\ vlaho.akmadzic@gf.sum.ba
}

\begin{abstract}
The paper presents the structural design of a toll station building on the highway. The subject building consists of two different types of structures, a reinforced concrete skeleton structure of ground floor with a flat roof and a steel structure of the canopy. Two reinforced concrete columns that support the canopy rise above the flat ground floor building. This is also the connection between the concrete and steel structure. All structural elements are calculated according to the current Eurocode regulations and National Annexes.
\end{abstract}

Key words: construction, reinforcement, steel sections, load, bearing capacity, serviceability

\section{Konstrukcija objekta naplatne postaje na autocesti}

Sažetak: $U$ radu je prikazan projekt konstrukcije objekta naplatne postaje na autocesti. Predmetni objekt sastoji od dvije različite vrste konstrukcija, armiranobetonske skeletne konstrukcije prizemlja $s$ ravnim krovom i čelične konstrukcije nadstrešnice. Iznad ravnog prizemnog objekta izdižu se dva armiranobetonska stupa na koja se oslanja nadstrešnica. To ujedno predstavlja i vezu betonskog i čeličnog objekta. Svi konstruktivni elementi proračunati su prema važećim Eurocode propisima i nacionalnim dodacima.

Ključne riječi: konstrukcija, armatura, čelični profili, opterećenje, nosivost, uporabljivost 


\section{INTRODUCTION}

The location of the toll station building on the highway is planned on the route of the future highway through Central Bosnia near Vitez. The structure is situated at $521 \mathrm{~m}$ a.s.l. on a plot with an area of approximately $2000 \mathrm{~m}^{2}$. The position of the building on the plot is the consequence of the spatial and traffic conditions, and the need results from the development of transport infrastructure and the increase in traffic congestions. The guidelines and course of project development follow the recommendations of PC "Autoceste FBIH" regarding the uniformity of construction solutions on highways. The soil at the building site is gravelly and according to Eurocode 7 is classified as category $B$ soil.

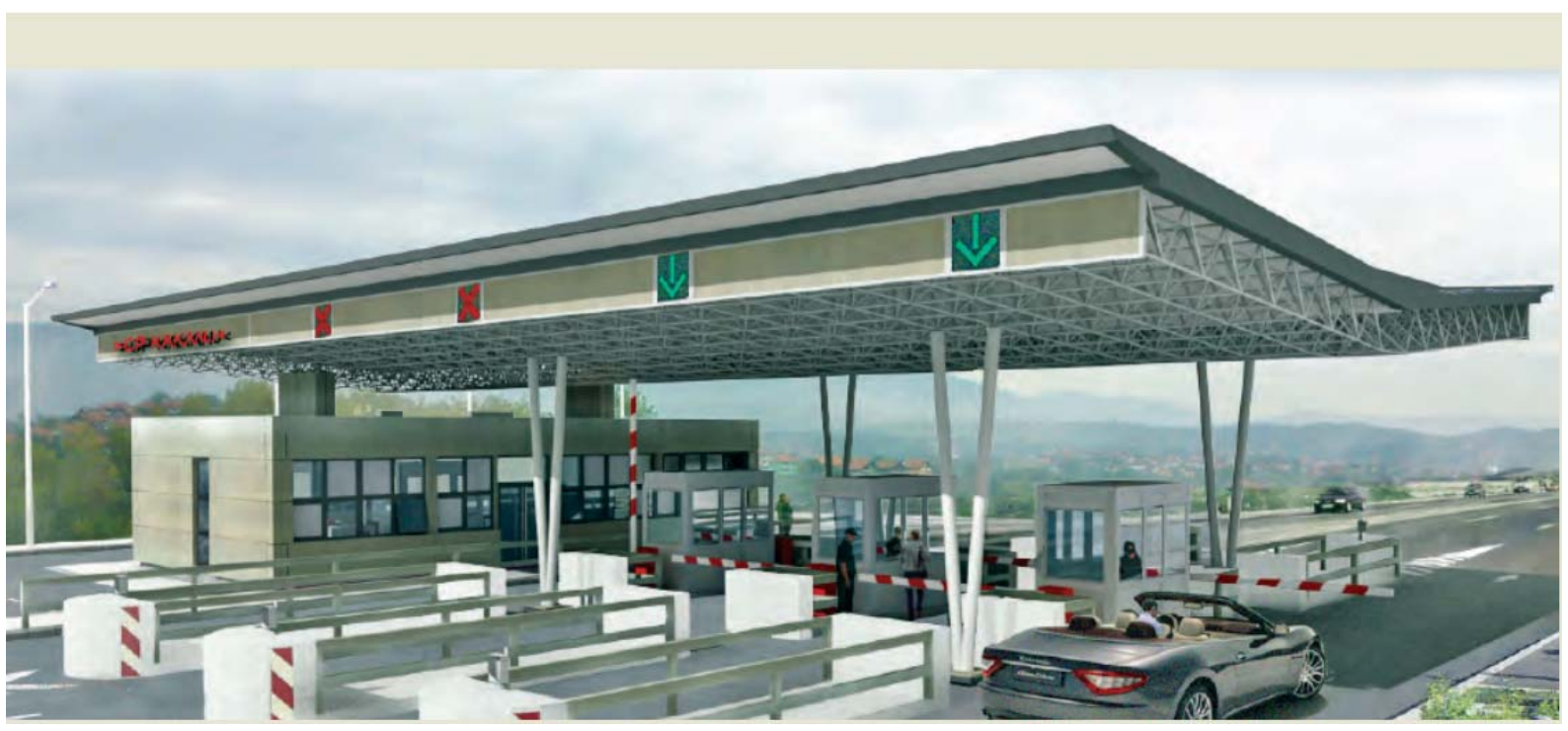

Figure 1. Visualization of the structure according to the conceptual design [21]

\section{STRUCTURAL DETAILS OF RC BUILDING}

In structural terms, the ground floor building is a reinforced concrete frame structure [8], [9], [10], [16]. The roof of the toll building is a serviceable flat roof above which there is a roof of the steel canopy. Above the ground floor toll building, the canopy rests on two RC columns where, due to the main girder grid, a short cantilever is made, and the connection of the toll building with the canopy is established at elevation $+6.00 \mathrm{~m}$.

The thickness of the flat roof slab is $20 \mathrm{~cm}$ and due to the height limit it is divided by beams with a total height (with slab) of $45 \mathrm{~cm}$. The longitudinal beam divides the slab longitudinally into two parts. It is located in the middle and connects the columns on which the canopy rests. Two transverse beams with a total height of $45 \mathrm{~cm}$ and width of $60 \mathrm{~cm}$ are also located at the level of the flat roof slab.

The connection between the ground floor and the serviceable roof is established by an external two-flight staircase with a plate thickness of $15 \mathrm{~cm}$ and flight width of $100 \mathrm{~cm}$. The staircase is made of eighteen treads $30 \mathrm{~cm}$ wide and $16 \mathrm{~cm}$ high. The intermediate landing is $120 \mathrm{~cm}$ wide. Stone cladding and aluminum railing are planned on the staircase.

The perimeter walls of the flat roof are parapet walls with a total height of $100 \mathrm{~cm}$. The columns of the ground floor are $40 \times 60 \mathrm{~cm}$ in size and are supported by pad foundations measuring $150 \times 150 \times 80 \mathrm{~cm}$ [6], [7]. Strip foundations are under the RC walls [12]. The pad 
Lozančić, M., Akmadžić, V.

Construction of toll station building on the highway

foundations are connected with the strip foundations by $60 \mathrm{~cm}$ high ground beams, which are integrated into a $15 \mathrm{~cm}$ thick floor slab. The foundation should be carried out in well-compacted soil. According to the geotechnical study, the expected bearing capacity of soil is $\geq 250 \mathrm{kPa}$, which is not exceeded.

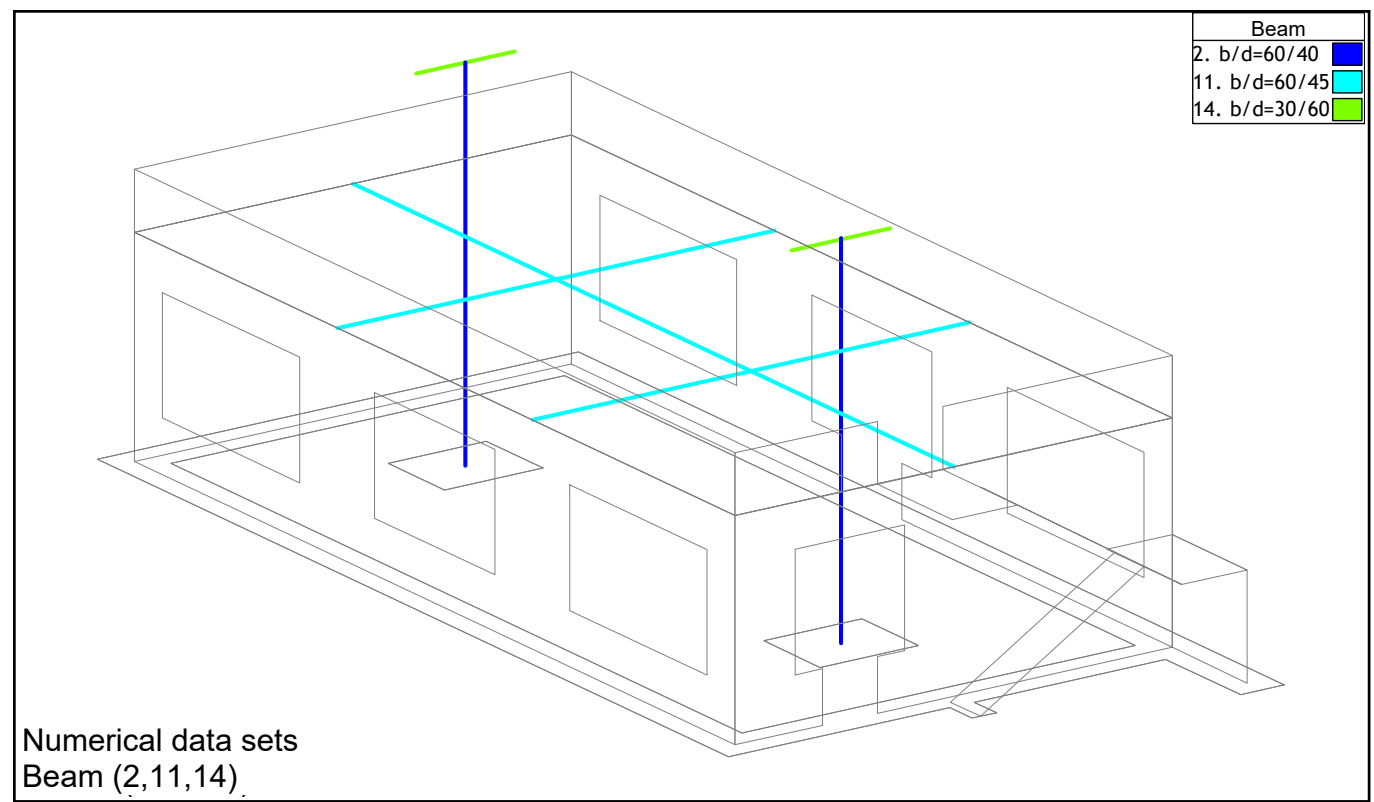

Figure 2. View of the RC building [Tower 8]

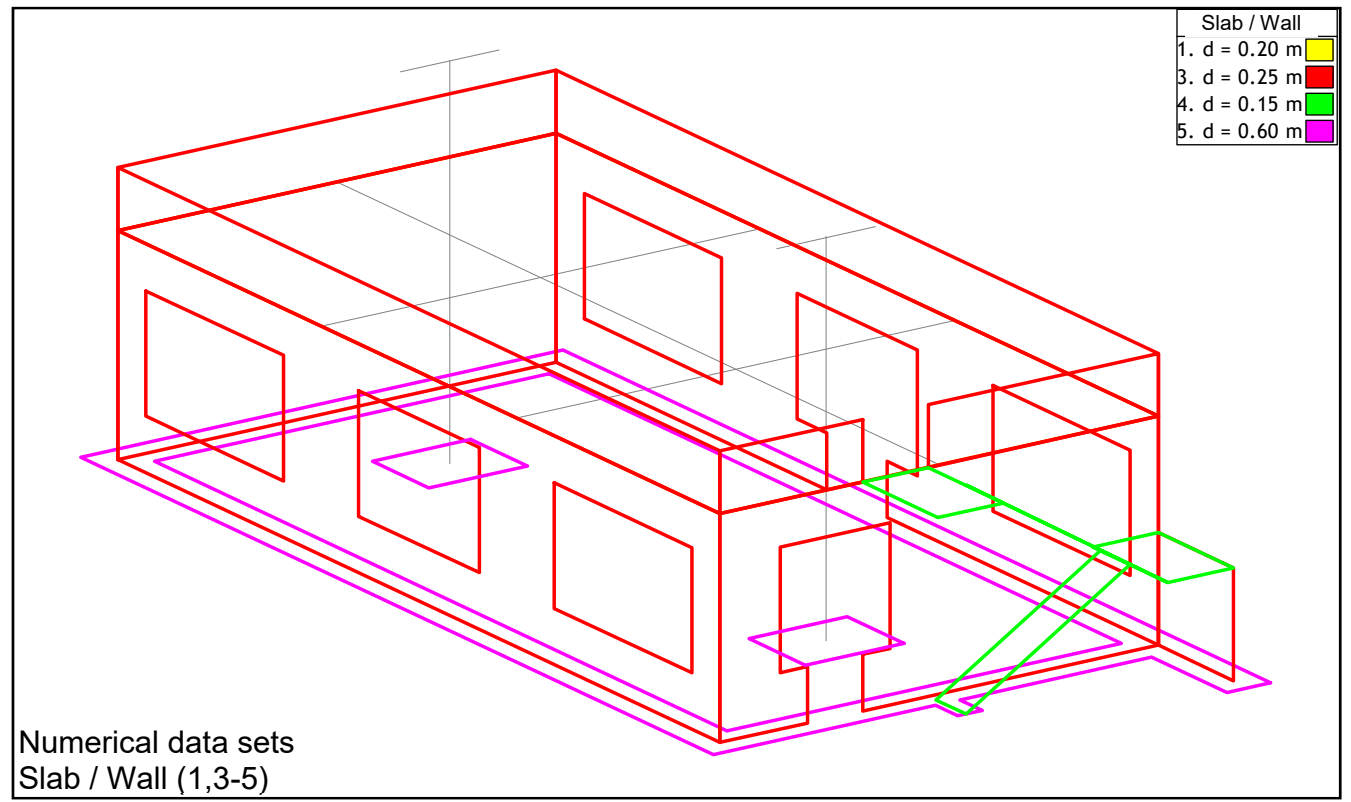

Figure 3. View of the sets of beams and columns [Tower 8] 
Lozančić, M., Akmadžić, V.

Construction of toll station building on the highway

\section{STRUCTURAL DETAILS OF THE STEEL CANOPY}

The canopy is designed as a structure made of rolled steel sections of grade S235 [3], [4], [5]. The dominant load of the canopy acts over the thermal panels of the roof surface, and is transferred to secondary girders. The secondary girders are placed in the direction of the longer dimension of the canopy (perpendicular to the traffic lane). The secondary girders are designed as continuous beams made of IPE 270 sections and are supported by main girders.

The characteristic span of the secondary girders between beams is $9.20 \mathrm{~m}$, and on the overhang (cantilever part) it is $3.50 \mathrm{~m}$. The distance between them is $1.80 \mathrm{~m}$. Extensions of the secondary girders are made using front plate and high-strength bolts. In order to make optimal use of the material, the secondary girder is composed of four segments: two segments of $12.00 \mathrm{~m}$, one of $6.00 \mathrm{~m}$, and one of $11.80 \mathrm{~m}$. It is important to emphasize that tension elements, installed as crossed diagonals with a cross section of $\varnothing 20 \mathrm{~mm}$, are also planned in the roof plane.

The main beam girders are installed parallel to the traffic lanes, follow the slope of roof surface $\left(6.7^{\circ}\right)$ and take the load from secondary girders. The axis span of the main girders is $10.00 \mathrm{~m}$, and the cantilever overhang is $3.10 \mathrm{~m}$. Beam girders are placed in pairs above the column and short cantilever above the ground floor building. Namely, the column is V-shaped and for this reason the spacing of one pair of main girders at the top of the column is $1.80 \mathrm{~m}$.

The cross section of the main beam girder is IPE 360. Extension of this beam girder is made at the joint in the roof surface valley using front plate and high-strength bolts.

Canopy columns are steel columns of characteristic $V$ shape $(\varnothing 219.1 \times 6 \mathrm{~mm})$. They are made by joining their bottoms into a single section, while their tops are structurally interconnected for the transport and assembly purposes. These columns are connected with pad foundations sized $180 \mathrm{~cm} \times 180 \mathrm{~cm} \times 50 \mathrm{~cm}$ over a RC socket.

In order to follow the pattern for placing beams on $\mathrm{V}$ columns, it was necessary to place above the ground floor building RC columns with extension on top in the form of short cantilevers (Figure 4). The connection between the IPE 360 beam and the short cantilever is shown in Figure 6.

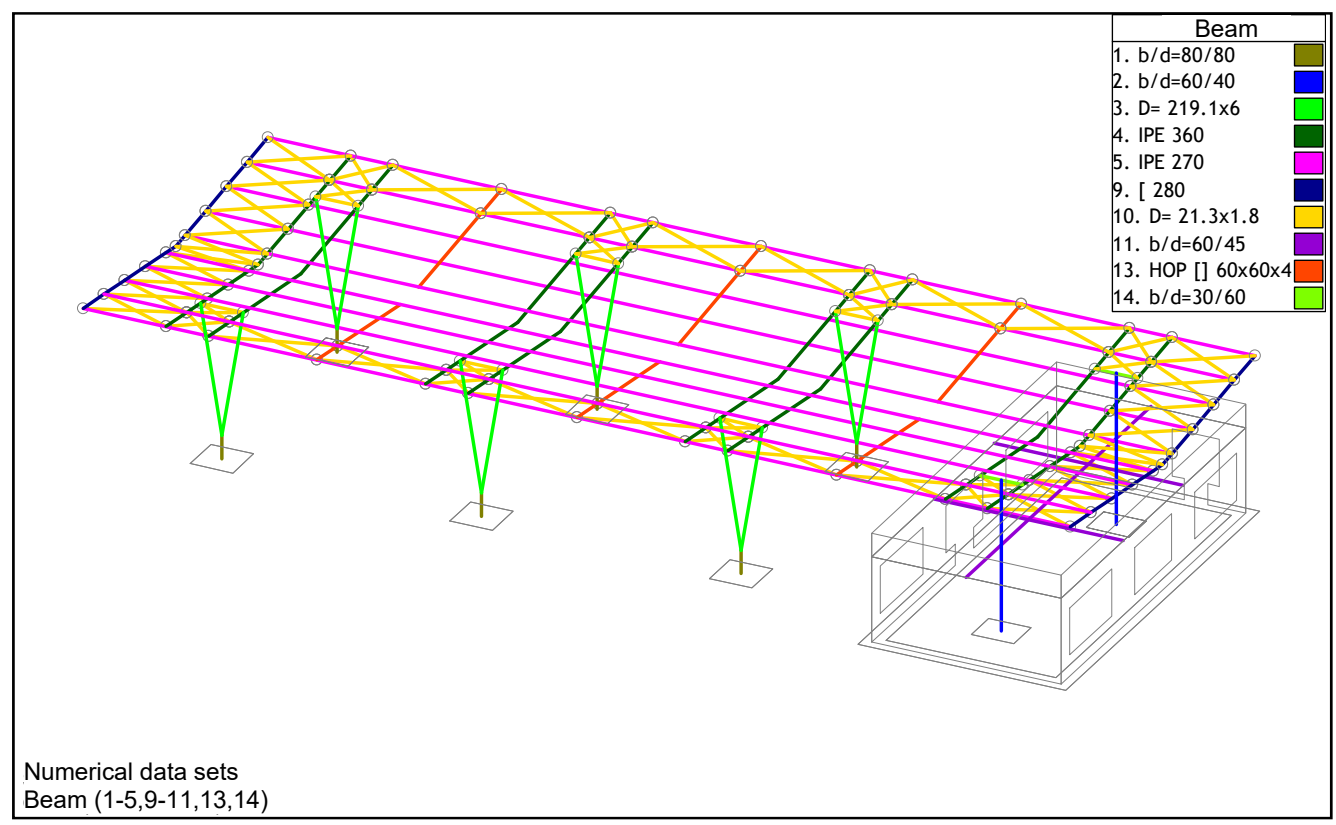

Figure 4. View of the canopy [Tower 8] 


\section{IN GENERAL ABOUT THE CALCULATION MODEL}

The structure was calculated in the TOWER 8 software suite from the Radimpex company. In this process, beams and columns were modeled as line elements of appropriate characteristics, and walls and slabs as appropriate plane elements [15], [18]. The soil was simulated using Winkler springs, set by the characteristics of surface support [1], [2], [19].

The following loads were considered in the analysis of the structure:

- Constant load of the structure (dead weight of plane and line elements),

- Additional constant load,

- Snow,

- Wind,

- Seismic accidental load.

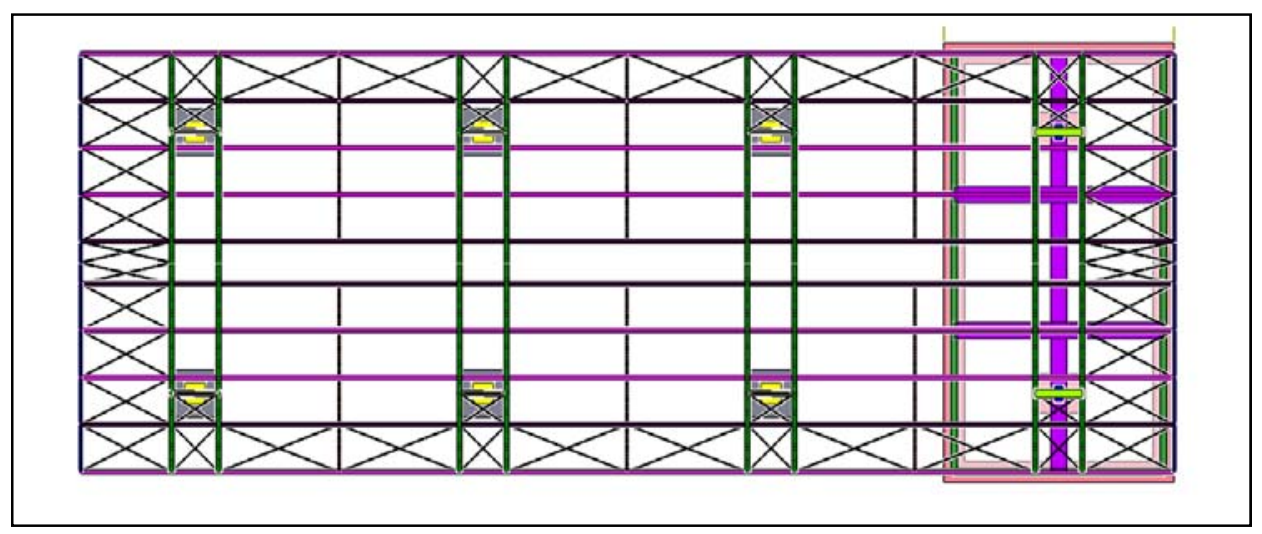

Figure 5. Base of the canopy roof [Tower 8]

\section{CHARACTERISTIC DETAILS}

The characteristic joints [11], [13], [14] for this structure are shown below. The first one is the connection between RC and steel structure, and it follows the line of reasoning of similar solutions [17]. The second one is the connection of the beam girder in the valley.

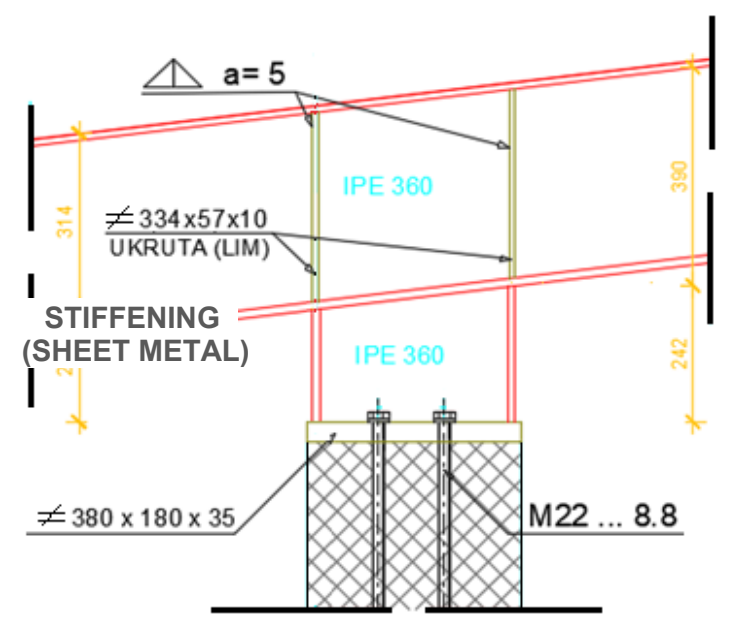

Figure 6. Connection of the short cantilever and the main girder 


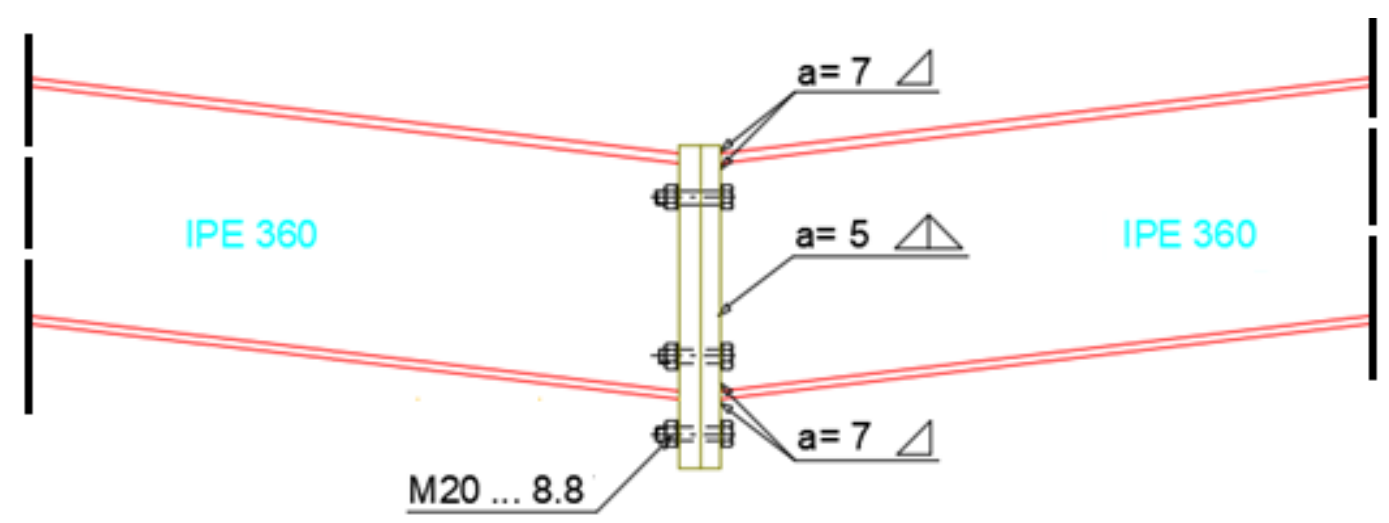

Figure 7. Connection of the main girder in the valley (for visibility reasons, the view of the weld is given on the right)

\section{RULES AND STANDARDS}

Buildings are designed and constructed with application of legislation in a particular area. In this case, it is European standards. European standards for structural design are based on a modern approach to structural analysis, and the idea of their creation is to establish uniform conditions for the design of building structures and other structures in European countries. In order to adapt these standards to the specifics of countries in terms of climate conditions, seismic area, etc. a National Annex marked as NA is issued for each standard. The basic parameters for snow (Figure 8), wind (Figure 10), and earthquake (Figure 11) loads were drawn from these annexes.

\subsection{Distribution of loads according to EC standards}

In addition to wind speed, for the effect of wind on the structure it is necessary to take into account the coefficients for the effects on canopies (Figure 9). Since the thermal panel rests on secondary girders, in the numerical model load was applied on secondary girders, which transferred the actions to main girders, and over the columns to the foundations and ground.

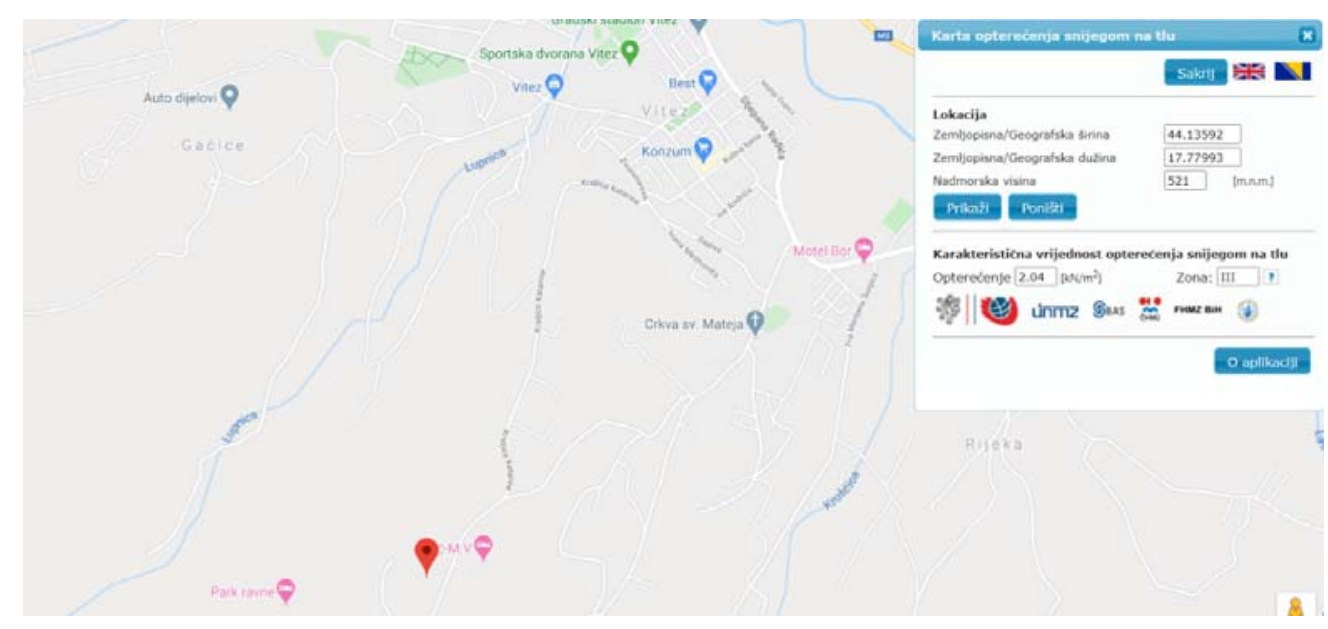

Figure 8. Map of snow load on the ground [20] 
Lozančić, M., Akmadžić, V.

Construction of toll station building on the highway

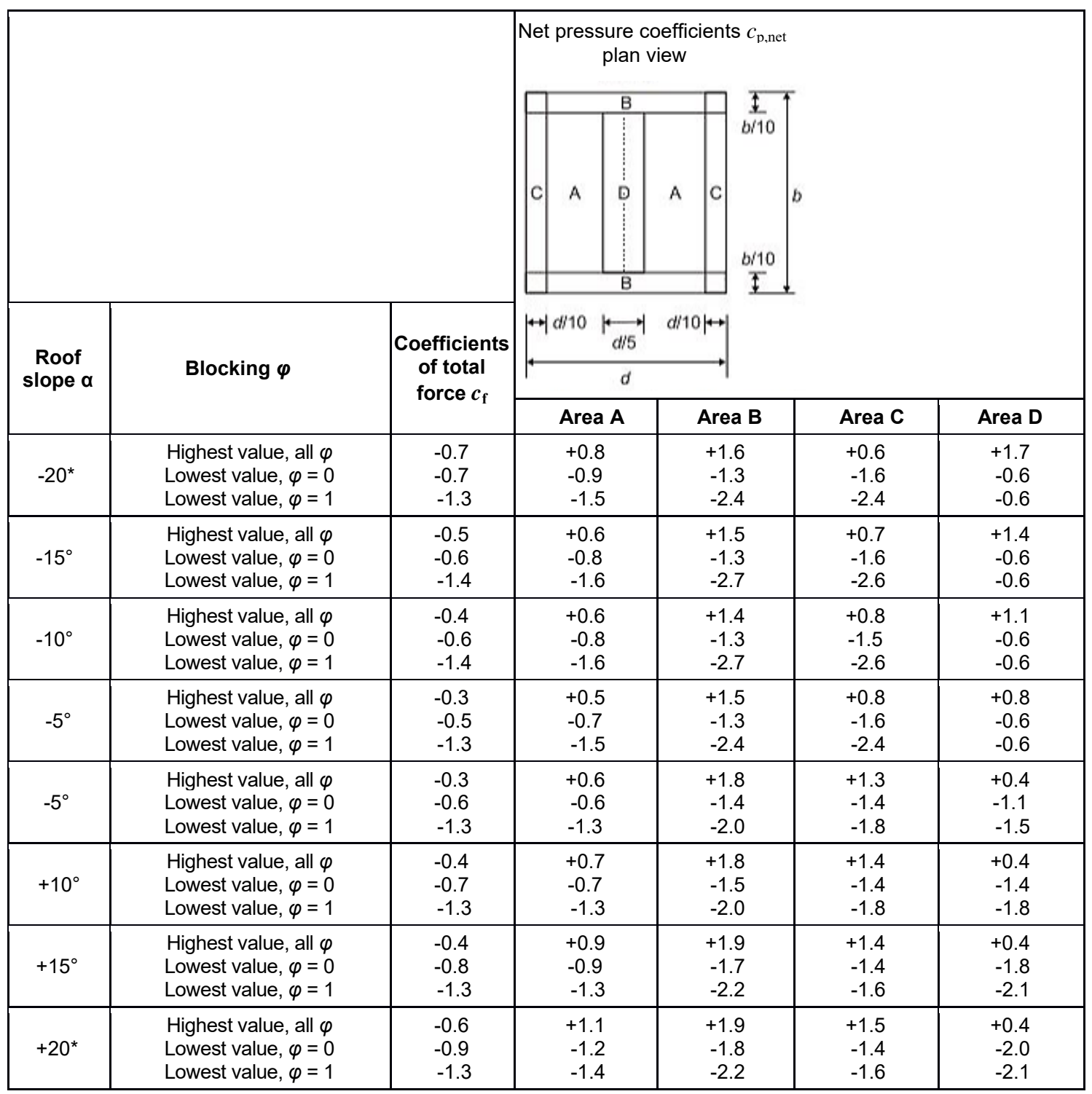

Figure 9. Value of net wind pressure $c_{p, n e t}[20]$

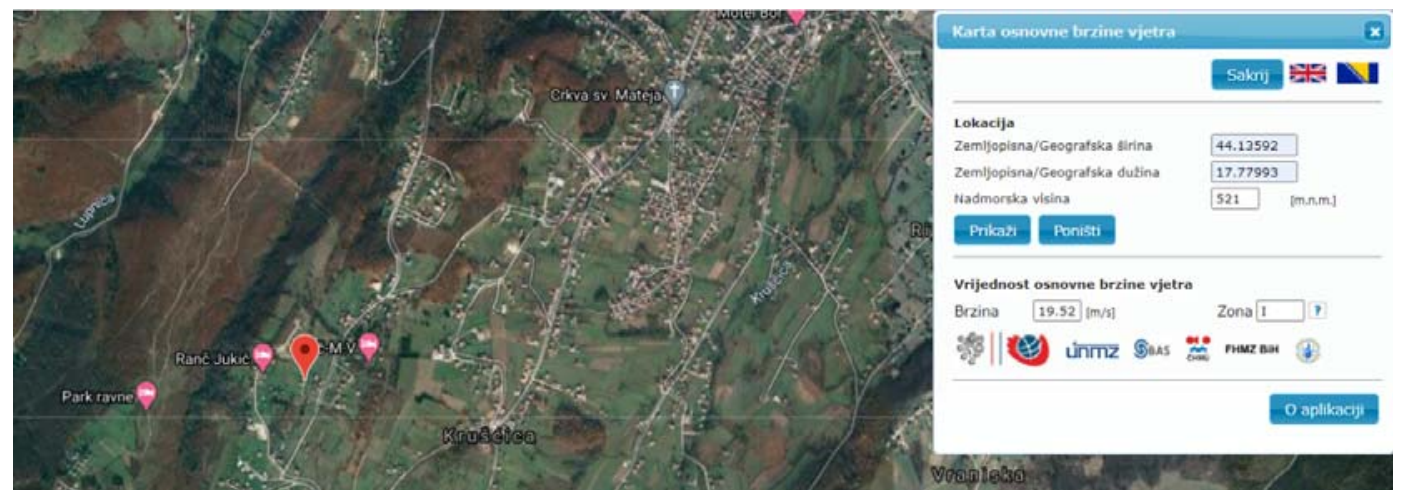

Figure 10. Map of basic wind speed [20] 


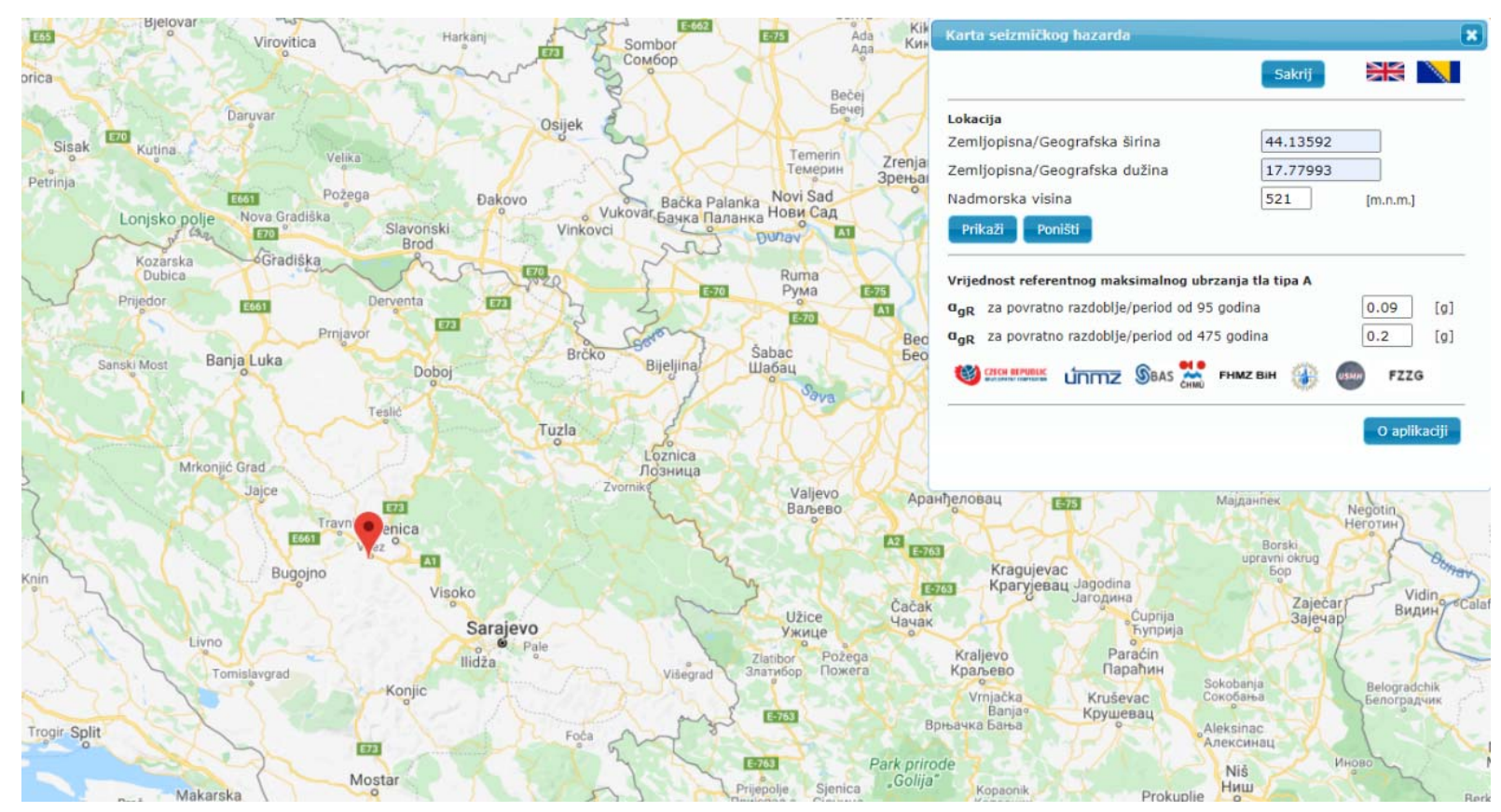

Figure 11. Map of maximum ground acceleration [20]

Concrete C $25 / 30$ is planned for concrete works, all according to the "Technical regulations for concrete structures", while C 16/20 can be used as base concrete. The basic material of steel structures used in the project is S $235 \mathrm{JR}$ and it satisfies all tests related to ultimate and serviceability limit states. When constructing connections of individual elements, generalpurpose bolts of class 8.8 were used. Reinforcement B500B in the form of bars and meshes is planned for all RC elements.

\section{CONCLUSION}

The choice of shape of the canopy structure was made based on instructions of PC "Autoceste $\mathrm{FBiH}$ " on the uniformity of structures on highways. The connection between the canopy structure and RC building was defined on the basis of economic, environmental and urban planning factors. RC skeleton system made of $\mathrm{C} 25 / 30$ concrete and $\mathrm{B} 500 \mathrm{~B}$ reinforcement was chosen for the ground floor building. The canopy beam system is made of hot-rolled sections and cold-formed sections, all made of grade S235 steel.

The main task was to perform the calculation and check whether the selected system meets the required level of mechanical resistance and stability.

During realization of the project, the most complex problem was the connection between the steel and concrete parts of the building. RC columns above the flat roof with short cantilevers supporting the canopy beams are selected in this solution. The characteristic shape of roof surface (valley) transfers large horizontal forces to the RC column.

Since the RC columns are essentially classic cantilever columns, which can be best seen in the displacement diagram, strong moments occur at the connection of the column with the RC slab of the flat roof. The consequence is the placement of maximum allowable reinforcement at the bottom of the column. A more detailed analysis of the behavior of structural elements leads to the conclusion that a better solution is to replace cantilever RC columns with $\mathrm{RC}$ wall panels on which the main canopy girders would rest. 


\section{REFERENCES}

1. Akmadžić, V., Vrdoljak, A.: Determination of the soil reaction coefficient value - software solution, e-ZBORNIK - Electronic collection of papers of the Faculty of Civil Engineering, 2018, No. 15, Vol. 8, pp. 21-28

2. Akmadzic, V., Vrdoljak, A.: Influence of soil reaction coefficient on 2D steel frame behavior, Proceedings of the 3rd International Conference on Engineering Sciences and Technologies, Košice, Slovakia, 2018, pp. 1-4

3. Androić, B., Dujmović, D., Džeba, I.: Metalne konstrukcije 1, IGH, Zagreb, 1994.

4. Androić, B., Dujmović, D., Džeba, I.: Metalne konstrukcije 2, IGH, Zagreb, 1994.

5. Androić, B., Dujmović, D., Džeba, I.: Metalne konstrukcije 3, IGH, Zagreb, 1994.

6. Glišić, M.: Fundiranje arhitektonskih objekata, Betonske konstrukcije, Prvo poglavlje, Beograd, 2004.

7. Gukov, I.: Concrete structures I, Lectures, Zagreb, 2017.

8. Harapin, A., Radić J.: Fundamentals of Concrete Structures, Internal course materials, Split, 2015.

9. Herak - Marović, V.: Reinforced concrete structures, Short elements, Lectures, Split, 2007.

10. Kraus, J.: Handbook with tables and expressions for calculation of effects on structures, FCE, J.J. Strossmayer University of Osijek, Osijek, 2018.

11. Leko, V.: Eurocode 3-1-8, Proračun spojeva, Komentari s primjerima, Slavonski Brod, 2012.

12. Markić, R., Miščević, P., Ćubela, D., Mikulić, Ž: Seizmički proračun potpornih zidova prema europskim normama (Seismic calculation of retaining walls according to eurocodes), e-ZBORNIK - Electronic collection of papers of the Faculty of Civil Engineering, 2016., No. 11, Vol. 6, pp. 100-117

13. Marković, Z., Buđevac, D., Tošić, D., Bogovac, D.: Metalne konstrukcije, Osnove proračuna i konstruisanja, Beograd, 2009.

14. Markulak, D.: Earthquake effects on structures and fundamentals of seismic calculation, Course Fundamentals of calculations and effects on structures, Presentation, FCE, J.J. Strossmayer University of Osijek, Osijek, 2016.

15. Mihanović A., Trogrlić B., Akmadžić V.: Građevna statika II., Faculty of Civil Engineering, Architecture, and Geodesy, Split, 2014.

16. Prskalo, M., Akmadžić, V., Vrdoljak, A.: Influence of subgrade reaction coefficient modelling on simple $3 \mathrm{~d}$ frame subjected to symmetric horizontal load, e-ZBORNIK Electronic collection of papers of the Faculty of Civil Engineering, 2019, No. 18, Vol. 9, pp. 38 $-46$

17. Ramljak, D., Akmadžić, V.: Modeling of urban villa structure, e-ZBORNIK - Electronic collection of papers of the Faculty of Civil Engineering, 2019, No. 17, Vol. 9, pp. 109-116

18. Ramljak D., Akmadzic $V$.: The influence of the mesh density and concrete quality on the results accuracy in thin plates, XVIII Anniversary International Scientific Conference by Construction and Architecture VSU'2018, Sofia, 2018, Volume 1, pp. 341-350.

19. Vrdoljak, A., Akmadzic, V.: Improvement of students' engineering skills in numerical modelling of the structural systems, Proceedings of the 18th International Symposium INFOTEH-JAHORINA, March 2019, pp. 20-22

20. www.eurokodovi.ba/?lang=hr, Priručnik za Eurokodove, Interaktivne karte

21. www.jpautoceste.ba, JP Autoceste FBIH, Set uputa za projektiranje, nabavku, ugradnju i održavanje elemenata, objekata ili dijelova objekata na autocesti, Sarajevo, 2013. 